\title{
Types of Speech Acts in the Short Film Nilep (2015)
}

\author{
Saleh Fahrudin ${ }^{1}$, Idawati $^{2}$, Salamah ${ }^{3}$ \\ \{sfahrudinn@gmail.com ${ }^{1}$ \} \\ Indonesian Language Education, Muhammadiyah University of Lampung, 35132, Indonesia ${ }^{1,2,3}$
}

\begin{abstract}
This study aims to describe the types of speech acts found in the short film Nilep (2015). The method in this research was descriptive method. The data in this study were in the form of illocutionary speech acts of speech interactions in the short film Nilep (2015). The steps taken in obtaining the data were by watching the short film, transcribing the utterances that appeared and reducing all the utterances to the types of speech acts. The results of the study found 29 speech acts types of speech, then the utterances were filtered into 6 speech acts based on the indicators. Based on the conclusion of the meaning contained in speech acts in the short film Nilep (2015), namely representative speech acts with indicators of showing and approving, directive speech acts with indicators of suggesting and commanding, expressive speech acts with indicators of blaming, and speech acts of declarations with indicators of deciding.
\end{abstract}

Keywords: Speech acts, type of speech, short film

\section{Introduction}

Language is used by humans as a means of communication in the form of a sound symbol system that comes from human speech tools. As a means of communication, language is a collection of words that have meaning. Every particular word has an abstract meaning and relationship with a concept or object that it represents. With language, speakers can communicate in a variety of ways and purposes. However, sometimes the speaker does not use the form of speech according to what he means in his speech. For example, when a speaker does not use a command sentence in ordering his interlocutor to do something he wants. When the speaker says "This room is very hot", the speech does not function to inform the other person about the state of the room at that time. However, with a declarative sentence the speaker indirectly wants the opponent to do an action, for example turning on the air conditioner, blowing a fan or opening a window. Speech is a form of action in the context of a speech situation, so that its activities are called speech acts. Speech acts are pragmatic analysis, which is a branch of linguistics that examines language from its actual usage aspect [1].

Divides the types of speech acts into five categories, namely representative, directive, expressive, commissive, and declarative speech acts [2]. Representative act is a language act to state the truth or a form of speech that binds the speaker to the truth of the proposition expressed. The directive action is meant by the speaker so that the interlocutor takes action according to what is stated in the speech. Expressive acts are intended by the speaker so that the speech can be interpreted as an evaluation of what is mentioned in the speech. Declarative acts are speech acts intended by the speaker to create new things (status, circumstances, etc.). 
This paper aims to describe the types of speech acts in the short film Nilep (2015). The theory used in classifying the types of speech acts in this study is the speech act theory discussed above.

\section{Method}

This research described the types of speech acts contained in the film Nilep (2015), therefore this type of research was a qualitative descriptive study. The research data source was the short film Nilep (2015). Nilep (2015) was a short film using the Javanese language. The data of this study were utterances containing the types of speech acts spoken by the players in the short film Nilep (2015). Furthermore, the data were obtained by making in-depth observations of the short film Nilep (2015). The steps were taken by watching the short film, transcribing the utterances that appear in the film, and reducing all the existing speeches into utterances that contain types of speech acts. The data that had been collected were then grouped and categorized based on the types of speech acts, then the speech data were analyzed and explained using meaningful sentences according to the existing speech act theory.

\section{Results and Discussion}

Just like the research that the researchers reviewed in this discussion, research similar to the author's research that discusses speech acts in short films had also been conducted by Septi Mariasari and Indriyati Hadiningrum, students of Jenderal Soedirman Purwokerto University, Central Java in 2019. The research discusses representative speech acts using Javanese in the communication media used in the short film. This study can be used as a reference in this study by discussing the types of speech acts in short films [3].

Previous research had also been conducted by Edo Frandika and Idawati, under the title Ilokosi's Speech Actions in the Short Film "Tilik (2018)". The research found that there were three forms of illocutionary speech acts and five types of illocutionary speech acts. The forms of illocutionary speech acts found were in the form of declarative, interrogative and imperative fillocutionar were five illocutionary speech acts, including assertive types, directive types, commissive types, declarative types, and expressive types [4].

Nilep (2015) is a short film that uses Javanese language which tells a group of children gathering at a security post. They argued about a child stealing a toy until they blame each other, until a friend insists on returning the stolen toy. Then a group of children accompanied one of the children who stole to return to the toy merchant's house. Arriving at the toy merchant's house, one of the children who stole did not dare to return it because in his mind the child had stolen, the toy dealer would beat him. Then they hurried back to go home. The toys that had been stolen were returned by sending packages to the toy dealer by writing a letter of apology for stealing their merchandise, namely the toy. In the short film Nilep (2015), types of speech acts appear in 9 utterances. The utterances were categorized into types of speech acts because they are representative, directive, expressive, and declarative speech. The speech was categorized into representative speech acts because the speech contains about agreeing and showing. Then it was categorized into directive speech because it contained suggestions or suggests, forces, orders, and orders. The type of speech act was expressive because it contained blaming speech, and the type of speech act was declared because the speech contained decisions or decisions. 
In representative speech acts, the speaker stated what was believed to be a fact, an affirmation, a conclusion, and a description. The speech in the short film Nilep (2015), which was included in representative speech acts, is speech that shows and agrees.

\subsection{Show}

Speech act shows that it is a representative type of illocutionary speech act, the speech act shows what the speaker says shows what he believes to the other person through his speech. Examples of demonstrated speech acts are:

Erlan : Ngerti Pak, iki ngko lurus. Ono pertelon kue nengen, umahe warnane ijo, ngarep umahe eneng wit peleme gedi.

(You know, sir, this is straight. Later there will be a T-junction to the right, the house is green, in front of the house there is a large mango tree)

Bayu : Ati-ati lho Pak, wonge galak. Wonge seneng mbrakoti.

(Be careful sir, he is fierce. He likes to bite)

In the speech "Ngerti Pak, iki ngko lurus. Ono pertelon kue nengen, umahe warnane ijo, ngarep umahe eneng wit peleme gedi." The speaker shows that the speech is evidence of a truth he believes by showing the address that someone is asking. Likewise with the following quote, which is a representative speech act by showing that the person he is looking for is a fierce person. "Ati-ati hlo Pak, wonge galak."

\subsection{Approve}

The speech act approves means that the speaker agrees or agrees with what is said by the other person or justifies, agrees, and accepts what is said.

Erlan : "Wegah! Pokok e yo wegah, wes to ayo bali wae! Bakule yo ra bakal ngerti kok nak sing nyolong dolanane aku."

(I don't want to! I just don't want to, let's just go home! The seller won't know if I took the toy.)

Bayu : "Ho oh bener, ayo muleh wae yok!"

(He's right, let's just go home!)

In the above speech, which includes the speech act of approving is the speech "Ho oh bener, ayo muleh wae yok!" (He's right, let's just go home!) The speech is a statement agreeing that the interlocutor will agree with what is conveyed by the speaker, namely a request from the speaker so that the interlocutor follows what he is doing.

The directive speech act has the potential to present power. The illocutionary power of this speech act requires the interlocutor to do something with the intention of the speaker. In the short film Nilep (2015), which includes directive speech in the form of suggesting and ordering.

\subsection{Advice}

Suggested speech acts are speech acts that suggest the speaker to do something good according to the speaker for the interlocutor himself. As in the following speech;

Ridho : "Tetep wae iso ngajari cah cilik udud. Aku wedi bapakku loro mergo udud."

(Still biased to teach young children to smoke. I'm afraid my father is sick because of smoking)

Afifah : "Mulakno sesok koe nak gede rasah udud, ben ra loro koyo bapakmu." 
(That's why you don't have to smoke when you grow up, so you don't get sick like your father.)

In the speech " Mulakno sesok koe nak gede rasah udud, ben ra loro koyo bapakmu." what Afifah said was a directive suggesting that the speech contained suggestions that the speaker gave to the other person so that when the opponent is older the interlocutor does not have to smoke so that it does not hurt like her parents.

\subsection{Governing}

The form of the command directive said that the command directive is a word that intends to order the interlocutor to do something [5]. In the type of command speech act there are functions of ordering, ordering, instructing, requiring, compelling, borrowing. The speech that shows the explanation above includes:

Afifah : "Ayo melu aku nang umahe bakule!"

(Come with me to the seller's house!)

Erlan : "Gah! Kesel."

(Don't want to! Tired.)

Afifah : "Ayoo melu!"

(Come on, come!)

This statement was conveyed when Erlan and Bayu stole the seller's toy, then Afifah ordered or forced to return it to the seller's house, but Erlan refused to return the toy.

Expressive speech acts are speech acts that are meant by the speaker so that the utterance is interpreted as an evaluation of what is mentioned in the speech [6]. In the short film Nilep (2015) there is a speech in the form of expressive speech acts, as follows:

\subsection{Blame}

Speech acts with a blaming indicator are indicated by the presence of speech from the speaker to the interlocutor who intends to blame the actions that have been done by the interlocutor or the party concerned with the speaker.
Afifah
: "Weh we ngawur e! Mesakke yo bakule."
(Uh you carelessly! Poor father.)
Erlan : "Bakule gaweane ngapusi og dimesakke."

(The salesperson's job is just a lie, pity ...)

In the speech "Bakule gaweane ngapusi og dimesakke..." what Erlan said was a directive speech with a blaming indicator. The speech contained a blaming indicator because according to Erlan, the seller always lied to lottery buyers who always didn't get a prize. From there, Erlan assumed that the seller always lied and blamed him.

Declaration speech acts are a type of speech act that changes the world through speech [7]. That declaration speech acts are utterances carried out by speakers with the aim of creating something new. In the short film Nilep (2015) which is included in the reclassified speech act, it is as follows:

\subsection{Decide}

This deciding speech act is a speech act performed by the speaker to make a decision. The speech below is an example of applying the form of a decided speech act. 
Erlan : "Wegah! Pokoke wegah, wes ayo bali wae! Bakule yo ora bakal ngerti og nak sing nyolong dolanane aku.”

(I don't want to! I just don't want to, let's just go home! The seller won't know if I took the toy.)

Bayu : "Ho oh bener, ayo muleh wae yok!'

(He's right, let's just go home!)

This story was shared by Erlan and Bayu with a group of other children when forced by one of their friends to return the stolen toy. When they wanted to return but Erlan and Bayu were afraid to return the toys, they decided to just go home.

\section{Conclusion}

The types of speech acts found in the short film Nilep (2015) were representative speech acts, directive speech acts, expressive speech acts, and declaration speech acts. In the short film Nilep (2015) these types of speech acts appear in 29 speeches. These utterances were categorized into types of speech acts because these utterances were indicators that correspond to the types of speech acts discussed in this paper. The twenty-nine utterances could then be categorized into 6 indicators of speech based on the types of speech acts, namely representative speech acts with indicators of showing and agreeing, directive speech acts with indicators of suggesting and commanding, expressive speech acts with indicators of blaming, and speech acts with declaration indicators decide.

\section{References}

[1] Mujiono, Perbedaan antara Semantik dan Prgamatik serta Liku-likunya. Malang: IKIP Malang, 2009.

[2] Rohmadi, Muhammad, Pragmatik: Teori dan Analisis. Yogyakarta: Lingkar Media, 2004.

[3] Septi Mariasari and Indriyati Hadiningrum 2019 Tindak Tutur Representatif dalam Film Pendek Polapike Episode Mati Lampu. Prosiding Seminar Nasional dan Call for papers, pp. 510-516; November 2019

[4] Edo Frandika and Idawati 2020 Tindak Tutur Ilokusi dalam Film Pendek "Tilik (2018)". Penaliterasi: Jurnal Pendidikan Bahasa dan Sastra Indonesia, Vol. 3, Issue 2 pp. 61-69; Oktober 2020

[5] Prayitno, Harun J, Kesantunan Sosiopragmatik. Surakarta: Universitas Muhammadiyah Press, 2011.

[6] Rustono, Pokok-pokok Pragmatik. Semarang: IKIP Semarang Press, 1999.

[7] Yule, George, Pragmatik. Yogyakarta: Pustaka Pelajar, 2006. 